\title{
Study of the Effectiveness of $1 \%$ Sodium Hypochlorite on Blood Samples Discarded in a Clinical Laboratory
}

\author{
Sneha Kukanur, C. Nagaraj* and G. Latha \\ Department of Microbiology, PES Institute of Medical Sciences and Research, \\ Kuppam - 517 425, Chittoor district, Andhra Pradesh, India \\ *Corresponding author:
}

A B S T R A C T

\begin{tabular}{|l|}
\hline K e y w o r d s \\
Sodium \\
Hypochlorite, \\
$\begin{array}{l}\text { Disinfectant, } \\
\text { Biomedical waste } \\
\text { management, }\end{array}$ \\
$\begin{array}{l}\text { Hospital infection } \\
\text { control practices }\end{array}$ \\
\hline Article Info \\
\hline $\begin{array}{l}\text { Accepted: } \\
\text { 20 July } 2018 \\
\text { Available Online: } \\
\text { 10 August } 2018\end{array}$ \\
\hline
\end{tabular}

Sodium hypochlorite is extensively used as a disinfectant in the health care industry for more than 150 years. There are lots of misconceptions are there even to this day regarding the dilution and time of exposure required for its disinfection action. National guideline on Biomedical waste published by the Ministry of Government of India in its recommendations on Biomedical Waste (BMW) rule of 2016 had suggested the use of 10 $\%$ Sodium hypochlorite which was later corrected as typographical error and changed to 1 $\%$ which is now followed in the BMW Rule - 2018. The current study was planned since available literature does not mention the lowest concentration of Sodium hypochlorite and shortest possible time required for decontamination. To estimate the optimum requirement of Sodium hypochlorite to be used for disinfection of discarded blood vacutainers, we took up this study which was also a requirement of the hospital to close one of the non compliance (NC) raised by one of the NABH assessors who contested that $1 \%$ is not sufficient to decontaminate laboratory waste, especially blood. The study was designed and executed in a period of three and a half month which not only showed that $1 \%$ of Sodium hypochlorite was sufficient to disinfect the blood samples collected by the laboratory but also the requirement of $20 \mathrm{~min}$. specified by CDC guidelines was not required and the organisms tested were killed within 10 minutes. In the study, 11 bacteriological species of medical importance have been tested for the efficacy of Sodium hypochlorite as a disinfecting agent.

\section{Introduction}

Scientific application of disinfectants and sterilants began approximately 150 years ago, although empirical use of disinfectants dates back to ancient time (Block, 1991; Rutala et al., 1995). In approximately 800 B.C., the Greek poet Homer reported the use of sulfur dioxide as a disinfectant in his classic tale of adventure, The Odyssey Swedish chemist Scheele's discovery of chlorine in 1774 helped in the age of chemistry. Frenchman Labarraque reported in 1825 , the use of calcium hypochlorite for the general sanitation of morgues, sewers, privies, stables, hospital wards, ships, and prisons. He also reported 
that Parisian surgeons achieved great success in cases of carbuncle, hospital gangrene, ulcers, and burns when the wounds were covered with dressings containing a diluted aqueous solution of hypochlorite (Block, 1991). During World War I, Dakin introduced the widespread use of a sodium hypochlorite solution (approximately 0.5\%) for antisepsis of open and infected wounds (Denys, 1989). Within a few years, chlorination was widely used in the United States (Dychdala, 1991; Ellis, 1991). Despite the introduction of many classes of disinfectants, hypochlorite products continue to play an important role in improving the public health by reducing crosstransmission of infectious agents via drinking water and environmental surfaces.

\section{Sodium hypochlorite}

This solution is among the top ten disinfectants used to control Hospital Acquired Infections (HAI). It is an intermediate - level disinfectant which is classified under Chlorine-releasing agents (CRAs). Chlorine in the form of hypochlorous acid, even in minute quantities exhibits rapid microbicidal activity. It is widely used for the disinfection of hard surfaces and blood spillages containing the human immunodeficiency virus or hepatitis B virus. Sodium hypochlorite is one of the commonly used disinfectants in a hospital. Its properties are a result of the equilibrium reaction between elemental chlorine and caustic soda. Presence of caustic soda is necessary to keep the $\mathrm{pH}$ at high values, thus avoiding the release of free chlorine (very toxic gas). Usually it is supplied as an aqueous solution. Chlorine is slowly liberated. It is very effective in its germicidal action. This action is due to the formation of hypochlorous acid when free chlorine reacts with water.

$\mathrm{Cl}_{2}+\mathrm{H}_{2} \mathrm{O} \rightarrow \mathrm{HCl}+\mathrm{HClO}$ ( hypochlorous acid)

The hypoclorous acid formed is further decomposed: $2 \mathrm{HClO} \rightarrow 2 \mathrm{HCl}+\mathrm{O}_{2}$

Oxygen released in this reaction (nascent oxygen) brings about microbial destruction by oxidation. Combination of chlorine with proteins of the cell membrane and enzymes is also responsible for the death of organisms. Its ability to pass through the cell membranes apart from its high chemical potential permits Sodium Hypochlorite to kill practically every kind of microorganism, even at low temperature and low concentration. Sodium hypochlorite has broad antimicrobial activity (William et al., 1991). It is diluted to varying degrees to suit specific applications. In the hospital, it is used as a disinfection agent in Hospital Infection Control (HIC):

- Antisepsis and dental therapy

- As a bleach and disinfectant in Laundry

- As a spill management agent

- Surface disinfectant

- Decontamination of sharps

- Disinfecting agent for safe drinking water supply including dialysis water (Hyper chlorination kills organisms such as Legionella and endospores)

- As a sterilizer in cleaning utensils used in hospital kitchen

Effluent control including purification of sewage and decomposition of cyanide waste.

\section{Materials and Methods}

This study mainly focuses on the use of Sodium hypochlorite as a disinfectant. Biomedical waste disposal is mandatory, legal and traceable. From a Clinical laboratory perspective, all laboratory infected waste has to be disinfected before handing over the waste to the authorized agency designated by the State government. Apart from culture media from the Microbiological laboratory, most important sample which goes out of the laboratory is the samples of blood. Blood also happen to be a good medium to transmit 
infections and easily gets contaminated from the environmental organisms including clinical pathogens which are lurking in the hospital environment. Blood borne pathogens such as HIV, HBV and HCV could be present in the discard samples if collected from patients suffering from these diseases. So we selected the blood samples for the current study. Before discard, as a policy of the laboratory, the samples are retained for a period of 72 hours before discard for future reference, redo or reorder procedures. During this period, though they are kept at $2-8{ }^{\circ} \mathrm{C}$, they continue to harbor or acquire bacteria from the environment.

Factors which influence antimicrobial activity of Sodium hypochlorite include concentration of the chemical used, time of exposure and temperature.

Aim of the study: This was to find the actual concentration and time of exposure required for effective decontamination of blood associated pathogens in the microbiology laboratory of the rural tertiary care hospital.

Study period was for a period of three and a half months ( $3^{\text {rd }}$ Feb. 2016 to $19^{\text {th }}$ May 2016). Daily discarded vacutainers were put into a designated double bucket (Fig. 1) with a separate lid. Using appropriate Personal Protective Equipments (PPE), vacutainer caps were opened to allow the contact of Sodium hypochlorite with the blood sample. A pretest sample of blood was collected using a sterile microbiological loop and directly streaked on to the Blood and Mac Conkey media. Freshly prepared $1 \%$ Sodium hypochlorite solution was poured into the bucket so that the sample of blood and vacutainers were completely immersed in the Sodium hypochlorite solution and the lid was closed. Hypochlorite solution was made to react with the blood and vacutainers for either 10 minutes, 20 minutes or overnight and post exposure cultures were taken on the Blood and Mac Conkey media plates. Pre and post exposure plates were incubated at $37{ }^{\circ} \mathrm{C}$ for 24 hours and observed for the growth of organisms and the organisms were identified by appropriate biochemical tests.

Inclusion criteria: All vacutainers discarded on each day irrespective of its pre contaminated state. There was no exclusion criteria defined for the study.

\section{Results and Discussion}

Samples were collected on 74 days during the study period which yielded 123 bacterial isolates (Some of the samples grew more than one organism) in the samples collected before exposure to $1 \%$ Sodium hypochlorite. Details of the samples yielding number of organisms are given in Table 1. Bacterial cultures were grown in $72 \%$ of the samples tested. Most of the samples tested had one $(32.43 \%)$ or two $(14.86 \%)$ organisms. There was no growth in 20 samples $(27 \%)$ tested. Sample distribution is depicted in Table 2. Important organisms isolated were Pseudomonas (around $25 \%$ ), E. coli $(17.89 \%)$ and Non - fermenting Gram negative bacteria - NFGNB (14.63\%).

Table.1 Depicting the number of organisms isolated per sample

\begin{tabular}{|c|c|c|c|c|c|}
\hline $\begin{array}{c}\text { No } \\
\text { growth }\end{array}$ & $\begin{array}{c}\text { one } \\
\text { organism }\end{array}$ & $\begin{array}{c}\text { Two } \\
\text { organisms }\end{array}$ & $\begin{array}{c}\text { Three } \\
\text { organisms }\end{array}$ & $\begin{array}{c}\text { Four } \\
\text { organisms }\end{array}$ & Total \\
\hline $\mathbf{2 0}$ & 24 & 16 & 11 & 3 & 74 \\
\hline $\mathbf{2 7 . 0 3}$ & 32.43 & 21.62 & 14.86 & 4.05 & 100.00 \\
\hline
\end{tabular}


Table.2 Depicting the distribution of study isolates before exposure to $1 \%$ Sodium hypochlorite

\begin{tabular}{|l|l|l|}
\hline Organism & No. of isolates & Percentage \\
\hline Aerobic spore bearers & 6 & 4.88 \\
\hline Burkholderia spp. & 1 & 0.81 \\
\hline CONS & 10 & 8.13 \\
\hline E. coli & 22 & 17.89 \\
\hline Enterococcus spp & 2 & 1.63 \\
\hline Klebsiella pneumoniae & 5 & 4.07 \\
\hline Klebsiella spp & 3 & 2.44 \\
\hline Micrococci & 2 & 1.63 \\
\hline NF GNB & 18 & 14.63 \\
\hline No growth & 20 & 16.26 \\
\hline Proteus spp & 1 & 0.81 \\
\hline Pseudomonas aeruginosa & 30 & 24.39 \\
\hline Pseudomonas spp. & 1 & 0.81 \\
\hline Streptococcus spp. & 2 & 1.63 \\
\hline Total & 123 & 100.00 \\
\hline
\end{tabular}

Table.3 Effect of exposure time of $1 \%$ Sodium hypochlorite on different Bacteria isolated from the stored vacutainers beyond 72 hours

\begin{tabular}{|l|r|r|r|r|}
\hline \multicolumn{1}{|c|}{$\begin{array}{c}\text { Bacteria isolated from } \\
\text { blood stored in vacutainers }\end{array}$} & $\begin{array}{c}\text { Neat sample } \\
\text { (Before exposure) }\end{array}$ & \multicolumn{4}{|c|}{ Time of exposure } \\
\hline Aerobic spore bearers & 6 & 0 & 0 & 0 \\
\hline Burkholderia spp. & 1 & 0 & 0 & 0 \\
\hline CONS & 10 & 0 & 0 & 0 \\
\hline E. coli & 22 & 0 & 0 & 0 \\
\hline Enterococcus spp & 2 & 0 & 0 & 0 \\
\hline Klebsiella pneumoniae & 5 & 0 & 0 & 0 \\
\hline Klebsiella spp & 3 & 0 & 0 & 0 \\
\hline Micrococci & 2 & 0 & 0 & 0 \\
\hline NF GNB & 18 & 0 & 0 & 0 \\
\hline No growth & 20 & 0 & 0 & 0 \\
\hline Proteus spp & 1 & 0 & 0 & 0 \\
\hline Pseudomonas aeruginosa & 30 & 0 & 0 & 0 \\
\hline Pseudomonas spp. & 1 & 0 & 0 & 0 \\
\hline Streptococcus spp. & 2 & 0 & 0 & 0 \\
\hline
\end{tabular}


Fig.1 Photograph depicting the double bucket used for disinfection of vacutainers

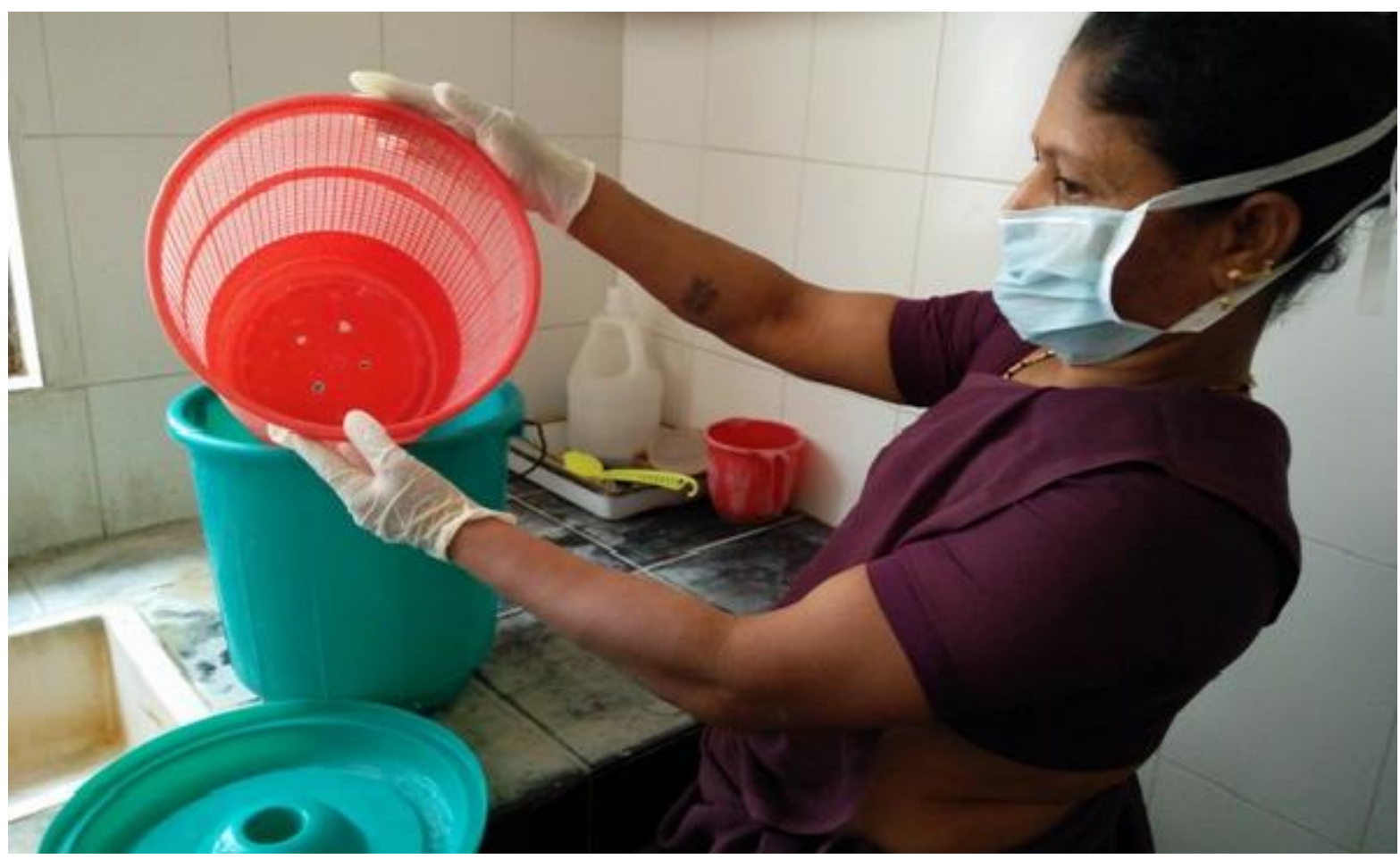

Effect of exposure time on the organisms to 1 $\%$ Sodium hypochlorite is depicted in Table 3 wherein, all the 123 organisms exposed were killed within 10 minutes of exposure. The exposure time of just 10 minutes was sufficient to kill all the bacterial isolates studied. Efficacy of $1 \%$ Sodium hypochlorite was maintained at the maximum, since the dilution was prepared afresh, every time the study was conducted. BMW rule is mandatory, legal and traceable. All infected materials should be decontaminated at source itself and this is stringently followed up. BMW rule of 2018 states that all laboratory samples are decontaminated at source. The requirement of the percentage of Sodium hypochlorite to be used in the form of disinfectant is still debated (Chitnis et al., 2002). Though CDC recommends the use of 1 $\%$ Sodium hypochlorite to decontaminate the biomedical waste, some question the safety and recommend upto $10 \%$. Higher doses of hypochlorite increase the release of more quantities of free chlorine which is a toxic gas
(Doris Horvath). So the sodium hypochlorite required to be used in optimum doses to achieve effective disinfection without affecting the health of the personnel involved need to be evaluated in the laboratory.

In the current study, a total of 123 bacterial isolates were studied on 74 samples of blood vacutainers which were stored over 72 hours. The current study helps to prove the clinical hypothesis (CDC guidelines) that $1 \%$ of Sodium hypochlorite is sufficient to achieve total disinfection of blood samples within 10 minutes of exposure. Further studies are required to identify the lowest concentration of Sodium hypochlorite required to disinfect different laboratory samples before they are discarded.

\section{Acknowledgement}

The authors wish to thank the management for all the encouragement to take up this study and to the staff of Department of 
Microbiology, PESIMSR, Kuppam, AP for their support.

\section{References}

Block, S. S. 1991. Historical review, p. 3-17. In S. S. Block (ed.), Disinfection, sterilization, and preservation, 4th ed. Lea \& Febiger, Philadelphia, Pa.

Rutala, W. A., and D. J. Weber. 1995. Use of chemical germicides in the United States: 1994 and beyond, p. 1-22. In W. A. Rutala (ed.), Chemical germicides in health care. Association for Professionals in Infection Control and Epidemiology, Inc., Washington, D.C., and Polyscience Publication, Morin Heights, Canada.

Denys, G. A. 1989. Microbiological evaluation of the medical SafeTEC mechanical/chemical infectious waste disposal system, abstr. Q-57. In Abstracts of the 89th Annual Meeting of the American Society for Microbiology 1989. American Society for Microbiology, Washington, D.C.

Dakin, H. D. 1915. On the use of certain antiseptic substances in the treatment of infected wounds. Br. Med. J. 2:318-320.

Dychdala, G. R. 1991. Chlorine and chlorine compounds, p. 131-151. In S. S. Block (ed.), Disinfection, sterilization, and preservation, 4th ed. Lea \& Febiger, Philadelphia, Pa.

Ellis, K. V. 1991. Water disinfection: a review with some consideration of the requirements of the third world. Crit Rev Environ. Control 20:341-407.

William A. Rutala and David J. Weber (1997) Uses of Inorganic Hypochlorite (Bleach) in Health Care Facilities Clinical Microbiology Reviews; $\underline{10}$ : $597-610)$.

Doris Horvath (1992) Chlorine, chlorine compounds and their environmental impact. In: STOA Scholar seminar report. pp $1-42$.

BMW Rule BMW Rule (2016) [Published in the Gazette of India, Extraordinary, Part II, Section 3, Sub-section (i)] pp 1 $-37$.

BMW Rule 2018 (2018) [Published in the Gazette of India, Extraordinary [PART II-SEC. 3(i)] pp 1- 12.

V Chitnis, DS Chitnis, S Patil, S Chitnis (2002) Hypochlorite (1\%) is inefficient in decontaminating blood containing hypodermic needles. Indian Journal of Medical Microbiology, (2002) 20 (4):215-218.

\section{How to cite this article:}

Sneha Kukanur, C. Nagaraj and Latha, G. 2018. Study of the Effectiveness of $1 \%$ Sodium Hypochlorite on Blood Samples Discarded in a Clinical Laboratory. Int.J.Curr.Microbiol.App.Sci. 7(08): 3689-3694. doi: https://doi.org/10.20546/ijcmas.2018.708.374 